\title{
PROFITABILITY ANALYSIS AND DETERMINANTS OF GROUNDNUT (Arachis hypogea) PRODUCTION IN DAMBATTA LOCAL GOVERNMENT AREA OF KANO STATE, NIGERIA
}

\author{
${ }^{* 1}$ Onuwa, C. G., Mailumo, S. S. and Muhammed, S. Y.
}

*lDepartment of Agricultural Extension and Management, Federal College of Forestry, Jos, Plateau state, Nigeria.

*1Phone: 08035606473 Email: onuwag@ gmail.com

\begin{abstract}
This study analyzed the profitability and determinants of groundnut production in Dambatta Local Government Area of Kano state. Multistage sampling technique was used in collecting data from eighty (80) respondents in the study area. The data generated were analyzed using descriptive statistics, farm budgeting model and regression analysis. The results revealed that the gross margin and net farm income of the farmers were $\$ 71400 /$ ha and $\$ 59400 /$ ha respectively. Also, the fixed and operating ratios were estimated at 0.1 and 0.41 respectively, while the benefit- cost ratio was $\$ 1.98$. The coefficient of multiple determination $\left(\mathrm{R}^{2}\right)$ was 0.739 , implying that about $74 \%$ of the variation in the output of groundnut was accounted for by the explanatory variable inputs in the regression model. The regression coefficients of Farm $\operatorname{size}\left(\mathrm{X}_{1}\right)$ and $\mathrm{Credit}\left(\mathrm{X}_{6}\right)$ were positive and statistically significant at $(\mathrm{p}<0.01)$, labour $\left(\mathrm{X}_{2}\right)$ and Agrochemical $\left(\mathrm{X}_{5}\right)$ were also positive and statistically significant at $(\mathrm{p}<0.1)$, while Fertilizer $\left(\mathrm{X}_{4}\right)$ was also positive and statistically significant at $(\mathrm{p}<0.05)$. The major constraints associated with groundnut production in the study area include; inadequate capital (86\%), high cost of production inputs (83\%) and lack of access to agricultural credit (78\%). The study recommended that if these constraints are adequately tackled the productivity and profitability of the groundnut farmers will significantly improve.
\end{abstract}

Keywords: Constraints, determinants, groundnut, productivity, profitability

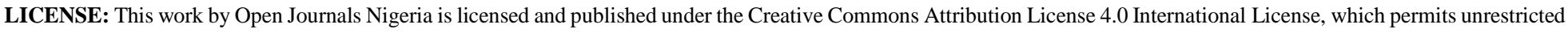
use, distribution, and reproduction in any medium, provided this article is duly cited.

COPYRIGHT: The Author(s) completely retain the copyright of this published article.

OPEN ACCESS: The Author(s) approves that this article remains permanently online in the open access (OA) mode.

QA: This Article is published in line with "COPE (Committee on Publication Ethics) and PIE (Publication Integrity \& Ethics)". 


\section{INTRODUCTION}

Groundnut (Arachis hypogea) is the $13^{\text {th }}$ most important food crop of the world (FAO, 2011). It is the world $4^{\text {th }}$ most important source of vegetable protein. Groundnut seeds contain high quality edible oil (50\%) easily digestible protein (25\%) and carbohydrate (20\%) groundnut is grown in nearly 100 countries with China, India, Nigeria, USA and Indonesia and Sudan's major producers (National Peanut Council, 2006). Before the world war Nigeria's groundnut expert figured prominently in world trade, accounting for $29 \%$ of Africa's expert and $12 \%$ of the world expert in the 1950 's world expert. In the early 70 's, Nigeria accounted for $41 \%$ of the total groundnut production in West Africa (Adesinmi 2003). The role of Agriculture in providing food and cash crop security, thereby reducing poverty cannot be over emphasized. It is in this light that Nigeria's agricultural policy focused on developing a progressive, dynamic and viable agricultural economy that would ensure food security, income growth and hence poverty reduction as well as promoting sustainable agriculture and a thriving Agricultural (Agric) business sector (NAERLS, 2011). It is estimated that over $90 \%$ of the farm holders in Nigeria are small scale; similarly, most of these farmers produce is subsistence basis and thus, face cash insecurity problems. It is in the light of this that many people believe that the production of cash crops such as groundnut is way out at such cash insecurity. Groundnut is cultivated in both tropical and sub-tropical countries. Groundnut believed to be the most popular and widely cultivated legume in Nigeria because of its adaptation to varied climatic conditions. Groundnut production in northern Nigeria is very pronounced and about 92\% of the national production comes from northern Nigeria (Gireiet.al. 2013). FAO (2011) estimated that Nigeria's cultivated area under groundnut cultivation is about 1.0-2.5million hectares annually and yield in the range of 500$3000 \mathrm{~kg} / \mathrm{ha}$. It was repented that seed yield in northern Nigeria's is about $3000 \mathrm{~kg} / \mathrm{ha}$ developing countries account for $92 \%$ and $96 \%$ of global output and production area respectively (FAO 2011).

\section{PROBLEM STATEMENT}

However, NAERLS (2011) laments that groundnut yield in Nigeria has generally been poor due to a combination of socioeconomic factors affecting small-scale farmers. While some of these factors are outside the control of the farmers, others are within their control. Despite numerous crop improvement practices and innovations as reported by national peanut council (national peanut council, 2006). There seem to be a supply-demand deficit, hence there have been several reported cases of low productivity and profitability. Groundnut is mainly under taken by small holder farmers at subsistence level of production, using traditional methods, practices and technology (Gireiet.al. 2013). It is important to find out the extent to which certain factors constrain the efficiency levels of the groundnut farmers so that specific policies may be designed to improve farm productivity in the study area.

\section{OBJECTIVES OF THE STUDY}

The broad objective of the study is to analyze the profitability and determinants of groundnut production in Dambatta local government area of Kano State, while the specific objectives are to;

i) estimate the profitability of groundnut production;

ii) determine the input and output relationship of groundnut production; and

iii) identify the constraints of groundnut production in the study area. 


\section{HYPOTHESIS}

Ho: There is no input and output relationship in groundnut production.

\section{METHODOLOGY}

\section{STUDY AREA}

Dambatta is situated in northern part of Kano State it is enclosed between latitude $12^{\circ} 25^{\prime} \mathrm{N}$ and longitude $08^{\circ} 3055^{\prime} \mathrm{E}$ with a land mass of $2732 \mathrm{~km}^{2}$. Dambatta local government area is located in Dambatta town just about $40 \mathrm{~km}$ north east of Kano metropolis. It has a population of 207,968 and expansion rate of 6.2 -percent per-annum (NPC, 2006). It has a land mass area of $305.51 \mathrm{~km}^{2}$. Humidity at times rise up to $100^{\circ}$ percent with a daily maximum and minimum temperature of $33.1^{\circ} \mathrm{C}$ and $15.85^{\circ} \mathrm{C}$ respectively. Rainfall varies considerably from year to year ranging between $635 \mathrm{~mm}-889 \mathrm{~mm}$ and it reaches its peak from storms followed by tomatoes mainly during the month of May and at the end of the rainy season in September or early October (NAERLS, 2011).Most of the populations are small scale farmers producing food crops like groundnut, millet, sorghum, cowpea and moreover, villages that are located close to the nearby oasis irrigational project engage in production of rice, pepper, onions, tomatoes and wheat. In addition, they are livestock, goats, sheep and poultry.

\section{SAMPLING TECHNIQUE}

Multi-stage sampling technique was employed in the drawing of samples for the study. The first stage involved the systematic random selection of four districts in the study area out of ten (10), which included Dambattayamma, DambattaGabas, Ajumawa and Gwarabjawa and the final stage involved the random selection of 20 groundnut famers in each of the selected districts giving a sample size of 80 respondents from the sample frame provided by Agricultural Development Project (ADP) and Groundnut co-operative farmers association in the study area.

\section{METHOD OF DATA COLLECTION}

A well-structured questionnaire designed in line with the objectives of the study was used for the collection of data. The data collected for this study were obtained from primary sources. The primary data will be collected for this research through scheduled interviews and observations, using a well-structured questionnaire. A total of 80 questionnaires were administered to the respondents, which were all retrieved and found to be valid enough for further analysis, giving a response rate of $100 \%$.

\section{METHOD OF DATA ANALYSIS}

Budgetary techniques such as, farm budgeting tools (gross margin analysis, net farm income and profitability ratios) were used to analyze objective I. Multiple regression analysis was used to determine the effects of the variable inputs on the output of groundnut; this was used in analyzing objective ii. Descriptive statistics (frequency distribution and percentages) were used to analyze objective iii. Thus, combinations of statistical, budgetary and parametric techniques were used in the analysis of data collected. 


\section{FARM BUDGETING (PROFITABILTY) ANALYSIS}

The farm budgeting model used is expressed as follows as adapted by (Akinpele and Ogbonna, 2005):

G.M=TR-TVC

Where; G.M=gross margin, T. R=total returns, T.V.C=total variable costs

Also, N.F.I=G.M-TFC

Where; N.F. I=net farm income, GM=gross margin, TFC=total fixed cost

Total Cost $(\mathrm{TC})=\mathrm{TVC}+\mathrm{TFC}$

Where; TC=total cost, $\mathrm{TVC}=$ total variable cost, $\mathrm{TFC}=$ total fixed cost

$\mathrm{TR}=$ Total Revenue $(\#)$

$\mathrm{TR}=\mathrm{P}_{\mathrm{Y}} . \mathrm{Y}_{\mathrm{I}}$

$\mathrm{TC}=$ Total cost $(\mathbb{N})$

$\mathrm{TC}=\mathrm{TVC}+\mathrm{TFC}$

TVC $=$ Total variable cost $(\$)$

$\mathrm{TVC}=\mathrm{P}_{\mathrm{X}} \cdot \mathrm{X}_{\mathrm{I}}$

$\mathrm{P}_{\mathrm{Y}}=$ unit price of output produced $(\aleph)$

$\mathrm{P}_{\mathrm{X}}=$ unit price of variable inputs $(\mathrm{kg} / \mathrm{liter})$

$\mathrm{Y}_{\mathrm{I}}=$ quantity of output $(\mathrm{kg})$

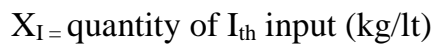

TFC =land rent, depreciation cost of assets ( $)$.

To determine the financial success of groundnut production the Benefit-cost, fixed and operating ratios were calculated. They are presented as follows:

$\mathrm{B}-\mathrm{C}=\mathrm{TR} / \mathrm{TC}$

Where; $\mathrm{B}-\mathrm{C}=$ Benefit cost ratio, $\mathrm{TR}=$ Total returns, $\mathrm{TC}=$ Total cost

\section{F. $\mathrm{R}=\mathrm{TFC} / \mathrm{TR}$}

Where; $\mathrm{F}$. R=fixed ratio, $\mathrm{TFC}=$ total fixed cost, $\mathrm{TR}=$ total return

O. $R=T V C / T R$

Where; $\mathrm{O} . \mathrm{R}=$ operating ratio, $\mathrm{TVC}=$ total variable cost, $\mathrm{TR}=$ total return

\section{REGRESSION ANALYSIS}

Data were also analyzed with the use of multiple regression analysis to estimate the input and output relationship in groundnut production. Four different functional forms (linear, semi-log, double log and exponential functional forms) were fitted to the data. The double-log function gave the best fit and was chosen as the lead equation on the basis of the number of significant variables, magnitude of the coefficients, statistical and econometric criteria and was used to analyze objective ii. The model in its explicit form is stated as follows:

$\log Y=b_{0}+b_{1} \log X_{1}+b_{2} \log X_{2}+b_{3} \log X_{3}+b_{4} \log X_{4}+b_{5} \log X_{5}+b_{6} \log X_{6+} e_{i}$ 
Where;

$\mathrm{Y}=$ Groundnut output/yield $(\mathrm{kg} / \mathrm{ha})$

$\mathrm{X}_{1}=$ Farm size; land area allocated to groundnut production (ha)

$\mathrm{X}_{2}=$ Quantity of groundnut seed used $(\mathrm{kg} / \mathrm{ha})$

$\times_{3}=$ Quantity of fertilizer used $(\mathrm{kg} / \mathrm{ha})$

$\mathrm{X}_{4}=$ Quantity of labour used (man-days/ha)

$\mathrm{X}_{5}=$ Quantity of agrochemicals used (lt/ha)

$\times_{6}=$ Access to agricultural credit $(1=\mathrm{yes}, 0=\mathrm{no})$

$\mathrm{b}_{0}=$ Intercept term showing the value of $\mathrm{Y}$ when $\mathrm{X}_{1}, \mathrm{X}_{2}, \mathrm{X}_{3}, \mathrm{X}_{4}, \mathrm{X}_{5}, \mathrm{X}_{6}$ is zero.

The a priori expectation is that $\mathrm{X}_{1}-\mathrm{X}_{6}$ will have a positive effect on production

\section{RESULTS}

The findings of the study are shown the tables below:

Table 1: Profitability (costs and return) analysis for groundnut production ( $\$ / \mathrm{ha}$ )

\begin{tabular}{lll}
\hline Variables & Amount (N/ha) & Percentage (\%) \\
\hline (A) Variable cost & 16,200 & 27 \\
(i) Labour & 2,400 & 4 \\
(ii) Seed & 18,400 & 30 \\
(iii) Fertilizer & 8,400 & 14 \\
(iv) Agro-chemicals & $\underline{3,200}$ & 5.3 \\
(v) Organic manure & $\underline{48,600}$ & \\
(B) Total Variable cost & & \\
(C) Fixed cost & 7,500 & 12.4 \\
(vi) Farmland rent & 4,500 & 7.3 \\
(vii) Depreciation cost of farm assets & & \\
& $\underline{12,000}$ & \\
(D) Total fixed cost & 60,600 & $\mathbf{1 0 0}$ \\
(E) Total cost (TC) & & \\
(TVC + TFC) & 120,000 & \\
(F) Total return & 71,400 & \\
(G) Gross margin (TR -TVC) & 59,400 & \\
(H) Net farm income (GM -TFC) & & \\
(I) Profitability ratios: & 1.98 & \\
(i)Benefit-cost ratio (TR/TC) & 0.1 & \\
(ii)Fixed ratio (TFC/TR) & 0.41 & \\
(iii)Operating ratio (TVC/TR) & & \\
\end{tabular}


Table 2:Estimated Regression (Double log production function) analysis for Groundnut production

\begin{tabular}{llcl}
\hline Variable & Coefficient & Standard error & T-ratio \\
\hline Constant & $3.212^{* *}$ & 1.369 & 2.346 \\
& & & \\
Farm size $\left(\mathrm{X}_{1}\right)$ & $0.348^{* * *}$ & 0.130 & 2.676 \\
Labour $\left(\mathrm{X}_{2}\right)$ & $0.205^{*}$ & 0.114 & 1.798 \\
Seed $\left(\mathrm{X}_{3}\right)$ & $-0.322^{*}$ & 0.177 & -1.819 \\
Fertilizer $\left(\mathrm{X}_{4}\right)$ & $0.561^{* *}$ & 0.252 & 2.226 \\
Herbicides $\left(\mathrm{X}_{5}\right)$ & $0.217^{*}$ & 0.132 & 1.644 \\
Credit $\left(\mathrm{X}_{6}\right)$ & $0.436^{* * *}$ & 0.152 & 2.868 \\
$\mathrm{R}^{2}$ & 0.739 & & \\
F Ratio & $6.912^{* * *}$ & & \\
& & & \\
\hline
\end{tabular}

***= significant at $(\mathrm{p}<0.01), * *=$ significant at $(\mathrm{p}<0.05), *$ significant at $(\mathrm{p}<0.1)$

Table 3: Constraints associated with groundnut production*

\begin{tabular}{lll}
\hline Constraints & Frequency & Percentage (\%) \\
\hline Inadequate capital & 69 & 86.25 \\
High cost of production inputs & 66 & 82.5 \\
Lack of extension contact & 29 & 36.25 \\
Fragmented farmlands & 44 & 55 \\
Post-harvest losses due to poor storage facilities & 37 & 46.25 \\
Poor access to improved production technology & 49 & 61.25 \\
Pest and diseases & 32 & 42.5 \\
Lack of access to agricultural credit & 62 & 77.5 \\
Total & & \\
$*$ = Multiple response & & \\
\hline
\end{tabular}

\section{DISCUSSION}

\section{PROFITABILITY (COSTS AND RETURN) ANALYSIS}

The cost and return analysis in Table 1reveals that the total cost of producing groundnut per hectare was estimated at $\$ 60,600$, while the estimated total revenue was $\$ 120,000$, Gross margin and net farm income were $\$ 71,400 /$ ha and $\$ 59,400 /$ ha respectively. From the analysis, the estimate of total variable cost was $\$ 48,600 /$ ha and the total fixed cost was estimated as $\$ 12,000 /$ ha. The major costs incurred in groundnut production were fertilizer (30\%), labor (27\%), Agro-chemicals (14\%), land rent (12.4\%) and depreciation cost of farm assets (7.3\%).Also the benefit cost ratio was estimated to be 1.98 which indicates that groundnut production is profitable in the study area; hence the 
profitability index was estimated to be greater than one (1.98, therefore P.I>1). Thus, the farmer earned $\$ 1.98$ on every naira spent on groundnut production. The fixed and operating ratios were 0.28 and 0.33 respectively, implying that groundnut production in the study area was relatively profitable. Hence, groundnut production in the study area is a very viable farm enterprise that has the capacity to improve the living standards of the rural farmers.

\section{REGRESSION (DOUBLE LOG FUNCTION) ANALYSIS}

The production function analysis presented in Table 2 (the double log function as the lead equation) was used to determine the input and output relationship in groundnut production. The result of the regression model fitted to analyze the determinants of productivity reveals that the coefficient of multiple determinations $\left(\mathrm{R}^{2}\right)$ was 0.739 implying that $74 \%$ of the variation in the output of groundnut was accounted for by the explanatory variable inputs in the model. The remaining $26 \%$ not explained may be due to omitted variables and the stochastic error term. The regression coefficients of Farm size $\left(\mathrm{X}_{1}\right)$ and $\operatorname{Credit}\left(\mathrm{X}_{6}\right)$ were positive and statistically significant at $(\mathrm{p}<0.01)$, Labour $\left(\mathrm{X}_{2}\right)$ and Agrochemical $\left(\mathrm{X}_{5}\right)$ were also positive and statistically significant at $(\mathrm{p}<0.1)$, while Fertilizer $\left(\mathrm{X}_{4}\right)$ was also positive and statistically significant at $(\mathrm{p}<0.05)$, this implies an increase in these positive endogenous variables,

holding other factors constant will lead to an increase in gross output. From the result, $\mathrm{X}_{1}, \mathrm{X}_{2}, \mathrm{X}_{4}, \mathrm{X}_{5}$ and $\mathrm{X}_{6}$ had positive coefficients, this implies that any $1 \%$ increase in these inputs would increase groundnut output by $0.34 \%$, $0.32 \%, 0.56 \%, 0.21 \%, 0.33 \%$ respectively. This conforms to the findings of Girei et al., (2013), Alabi et al., (2013) and Awoke, (2003). Only seed (X3) was negative and but statistically significant at $(\mathrm{p}<0.1)$. This negative coefficient of seed suggests an inverse relationship with gross (groundnut) output. The F-ratio (F 7.911) is significant at (P < 0.01 ), implying that the regression model significantly predicts the outcome variable. The variables significantly explained the variations in the gross (groundnut) output. Therefore, the regression model is good fit for the data, suggesting a linear relationship among the variables.

\section{CONSTRAINTS OF GROUNDNUT PRODUCTION}

The result of Table 3 revealed that a number of problems were identified confronting groundnut production in Dambatta local government area. From the result of this study the following production constraints were identified among groundnut farmers in the study area as presented in Table 3.The constraints include; inadequate capital (86.25\%), high cost of production inputs $(82.5 \%)$, lack of access to agricultural credit (77.5\%), poor access to improved production technology $(61.25 \%)$, fragmented farmlands $(55 \%)$, post-harvest losses due to poor storage facilities (46.25\%), pest and diseases (42.5\%) and lack of extension contact(36.25\%). All the constraints identified by the farmers significantly affected groundnut productivity in the study area.

\section{RECOMMENDATIONS}

Groundnut production in Dambatta local government area is a profitable venture as shown in this study. However, like other Agro business, it faces a lot of constraint's that need to be tackled to improve the situation. Improving groundnut production therefore requires that attention be paid to the following: 
- Groundnut farmers are enjoined to form producer cooperatives to enable them pool resources together to enhance their productivity.

- Governmental agencies should ensure that credit facilities are extended to farmers in groundnut producing areas. This will help in reducing the incidence of insufficient capital being currently faced by farmers.

- There is also need to assign more extension agents to attend to the farmers as this particular crop has not been given much attention by any governmental agency. Training should be constantly organized so as to keep farmers abreast of improved technologies in production.

- Improved land tenure practices should be adopted to reduce incidence of agricultural land fragmentation so as to enable them cultivate more land area for the crop. When farmers have access to reasonable hectarage of land, this will enable mechanization. To this end land use act should be appropriately amended.

- Government as well as other stake holders should ensure production inputs are subsidized for the farmers.

- Government as well as other stake holders should ensure adequate supply of improved production technologies to farmers.

- Farmers should also adopt appropriate measures in allocating their scarce resources such as land, capital, etc., and good management practices to bring about the much-desired increase in food production and food security

\section{CONCLUSION}

This study examined the economics of groundnut production in Dambatta Local Government Area in Kano State. The results indicate that majority of the respondents were males. Also, most of the farmers were literate and land acquisition for groundnut production in the study area is mainly through inheritance. Despite the various problems faced by groundnut farmers in the study area, groundnut production is profitable with an average total revenue of $\$ 120,000 /$ ha, giving a gross margin and net farm income of $\$ 71,400 /$ ha and $\$ 59,400 /$ ha respectively. Variation in groundnut output is explained by the variation in farm size, seed, fertilizer, agrochemicals and access to credit. Data analysis showed that the regression coefficients of the variable inputs in the model were positive and statistically significant at $(\mathrm{p}<0.05$ and $\mathrm{p}<0.01)$ level of significance. Farmers were however faced with some constraints, among the problems identified were lack of credit facility ranked first, followed by poor road network and the least problem recorded was inadequate extension contact. All the constraints identified were economically important in groundnut production. It is therefore recommended that effort should be channeled towards ameliorating these constraints. All stakeholders are encouraged to play their part in ensuring the survival and sustainability of groundnut production in Kano State. It is however believed, that with time and policy changes, these small-scale farmers will improve on their performance and grow to become major producers of groundnut in Kano state and in Nigeria in general. 


\section{REFERENCES}

Adesinmi, A. A. (2003). Prospects and potentials of groundnut cultivation as means of enhancing economic opportunities in the rural economy of northern Nigeria. Unpublished PhD. thesis, University of Wisconsin.

Alabi, O. F., Owonibi, B., Olafemi, S. O., Olagunju, S. (2013). Production analysis of groundnut in Birni Gwari Local Government Area of Kaduna State, Nigeria. PAT. 2013: 9(2):102-113.

Awoke, M. U. (2003). Production analysis of groundnut in Ezeagu Local Government Area of Enugu State, Nigeria. Global Journal of Agricultural Sciences. 2003; 2(2):138-142.

Food and Agriculture Organization-FAO. Report-FAOSTAT Production Year Book; 2011.

Girei, A. A, Dauna, Y. and Dire, B. (2013). Economic analysis of groundnut (Arachis hypogea) production in Hong Local Government Area of Adamawa State, Nigeria. Journal of Agricultural and Crop Research. 2013; 1(6): 84-89.

National Agricultural Extension Research and Liaisons Service (NAERLS). (2005). Arable crop manual (cotton, soya bean and groundnut). National accelerated industrial crop production program (NAICPP) Federal ministry of Agriculture Abuja.

National Agricultural Extension Research and Liaisons Service (NAERLS). (2011). Agricultural survey for 2011 wet seasons.

National Peanut Council. (2006). Peanut industry guide 2000-2001 the peanut farmer, 26(8): 270

National Population Commission (NPC) (2006). Report- Federal Republic of Nigeria; 2006.

Taru, V. B., Kyagya, I. Z., Mshelia, S. I. (2010). Profitability of groundnut production in Michika local government area of Adamawa State. Nigerian Journal of Agricultural Science. 2010; 1:25-29. 